\title{
Dealing with Maritime Economy at the Local Level. Trends along the Coastal Poland
}

\author{
Barbara Szejgiec-Kolenda ${ }^{1, *}$, and Jacek Zaucha ${ }^{2}$ \\ ${ }^{1}$ Institute of Geography and Spatial Organization, Polish Academy of Sciences, Twarda 51/55, 00-818 \\ Warsaw, Poland \\ ${ }^{2}$ University of Gdańsk, Faculty of Economics, Armii Krajowej 119/121, 81-824 Sopot, Poland; \\ Institute for Development, Czyżewskiego 6/1, 81-706 Sopot, Poland
}

\begin{abstract}
Although the interest in the concept of 'blue economy' has grown rapidly in recent years, the most studies assess maritime activities' size, scope, basic trends or position in national economy mostly at the basin/national, sometimes even regional level and there has been little research taking into account the local dimension of maritime economy. This is partly due to a lack of appropriate statistical data concerning maritime economy. The aim of the analysis is to define and describe the local maritime economy in Poland as well as to establish its importance for various territories. This study considers the challenges that maritime local studies face in terms of data availability and provides a research path that is to some extent complementary to analyses at the national and regional level. It explores a two-step approach to measure and evaluate a maritime local economy in Poland in 2016: (1) a more general countrywide attempt to identify the problem; (2) addressing the local dimension of blue economy in the spatially limited area (coastal regions). Moreover, the approach allows to identify territorial differences (functional region types), the extent to which these activities differ among local economies and the pathways for maritime economy structures transitions along the coastal Poland.
\end{abstract}

\section{Introduction}

An increase in interest in maritime economy along with growing potential for deriving benefits from the seas and the oceans wealth contributed to an increased intensification of efforts related with planning and strategic governance of maritime areas [cf. 1-4]. As a result, as of 2015, the Maritime Policy of the Republic of Poland up to 2020 (with perspectives up to 2030) [5] was adopted, whose main directions of development were determined earlier by the Green Paper on Marine Policy for the EU [6], as well as by the EU Strategy for the Baltic Sea Region [7].

In practical terms, there appeared demand for facilitating cohesion between scientific knowledge and governance practice to strengthen the decision-making processes and governance of economy and natural environment of seas and oceans, as well as of coastal

\footnotetext{
*Corresponding author: b.szejgiec@twarda.pan.pl
} 
zone. The Blue Economy, by providing considerable developmental opportunities for maritime regions and contributing to more rapid development of national economies, caused an increase of information requirements that are indispensable for public debate and development of national and international policies for sustainable sea governance. Over the quite short period of time the information gaps appeared on many dimensions: in terms of spatial approach "on land" (local, regional and national dimension of maritime economy), from a substantive perspective (identification of maritime sectors), from a subjective perspective (marine stakeholders), in the context of the definitional debate (measuring the marine economy) and in terms of tool-based approach (availability of coherent, comparable and adequate data, choice of measurement methods) [8].

The study comes within a contemporary discussions of maritime economy. The aim of the paper is to indicate specificity of defining the maritime economy on a local basis, and elaboration of measurement methods and evaluation of local maritime economy in Poland. Moreover, the study takes into consideration identification of spatial disparities, as well as searching for regularities in economic space of coastal regions in regard to blue economy in the context of usability of obtained findings in the process of governance.

\section{Theoretical and conceptual framework}

\subsection{Theoretical concepts of marine economy}

Studies aimed either at evaluation of economic activity associated with the oceans, or at delimitation of maritime functional regions or at development of other typologies of marine space are in the initial phase. Although one may try to describe the term "blue growth" explicitly as a broad economic use of seas' and oceans' resources, such as fisheries, shipping, tourism and coastal protection [9], the very terminology associated with seas and oceans is applied on a variety of ways in different parts of the world. There occur, for example, such terms as "ocean industry, "marine economy", "marine industry", "marine economy", "marine activity" and "maritime sector" [10].

Analogically, the scope of the marine economy is defined on multiple ways, depending on the particular countries and regions, which may pose problems while quantifying the economy's marine sectors. As shown by the example of United States, UK, France, Australia, China, Japan and South Korea, Park and Kildow [10] point out that disparities in understanding of marine economy are noticeable and may depend on the importance of the particular sectors in a given country. The common sectors of marine economy comprise such categories as: fisheries, marine mining, offshore oil and gas, ship and boat-building, marine manufacturing, marine construction, marine transportation, ports, marine tourism, ocean renewable energy, marine bio industry; and public sectors such as: education, national defence, $R \& D$, and public administration. Drawing on the aforementioned scope of marine economy sector, Parker and Kildow [10] break down maritime activities into activities that: (a) explore and develop ocean resources, (b) use ocean space, (c) protect the ocean environment, (d) use ocean products as a main input and (e) provide goods and services to ocean activities.

As far as the research studies in EU countries are concerned [11], the proposal is to take into account the following marine sectors: living resources, non-living resources, ship and boat building, construction, transportation, tourism and recreation, public administration, education and $R \& D$ and others, with making use of industries classified with the NACE Rev.2 four-digit numerical code. Suris et al. [11] break down the marine activities into three groups: completely marine, mainly marine and partially marine, 
pointing out at the same time that certain dose of flexibility ought to be preserved in defining the scope of maritime economy for the particular countries.

Similarly Colgan [12] distinguishes two concepts of economic activities falling under the framework of marine economy sector: (1) the ocean economy perceived as "economic activity which derives all or part of its input from the ocean" (p. 5), which is a function of both industry and geography" (p. 5), i.e. a significant part of activities takes place within the coastal regions, but some part maybe located outside those regions (e.g. seafood retailers), and (2) the coastal economy that is an economic activity in the coastal region and "incorporates a broader set of economic activity" (p. 5).

\subsection{Dimensions of local marine economy in practice}

Different approaches to concepts and definitions of maritime economy cause that the basic difficulty lies in delimitation of maritime economy. The EU public statistics omits to single out the sector of maritime economy. Inasmuch as, in Poland at the national level, the adequate estimates are carried out by the Polish Central Statistical Office [13]; one can hardly find relevant studies at the regional and local level, which comes along with limited access to statistical materials. Also there is a risk that defining maritime economy as a set of selected types of business activities may lead to both underestimation (registering in accordance with the prevailing kind of business activity, utilization of the enterprise method) as well as overestimation of the actual values (difficulty with distinguishing from types of business activities the particular ones that are strictly related to maritime economy). The information gap in the system of public statistics (both in Poland and in other EU countries; cf. 1) results from the inflexible or rigid system of data collecting, based on traditional breakdown into types of business activity, which makes it impossible to aggregate quantitative data with regard to sectors developing at variance with traditional breakdown (e.g. maritime economy or the so-called silver economy). It is necessary, in that case, to adopt lots of assumptions that as a result may lead to inaccurate conclusions.

The current study draws on EU experiences [cf. 14] which indicate selected types of business activity classification (NACE Rev.2 - PKD 2007) as referring to marine economy (Tab. 1). To some degree, also the concepts of marine economy are made use of, as proposed by Suris et al [11] and Colgan [12], basing the scope of marine economy on spatial scope of analysis (country vs. coastal areas). The Table 1 shows the types of activities, marked by grey background, when the analysis is restricted to maritime communes.

Table 1. Listing and grouping the types of business activities for the purposes of identification of maritime economy sector

\begin{tabular}{|l|l|}
\hline Types of activities by NACE Rev.2 - PKD 2007 classification (sectors and codes) & $\begin{array}{l}\text { Sector of maritime } \\
\text { economy }\end{array}$ \\
\hline $\begin{array}{l}\text { Marine (03.11) and freshwater (03.12) fishing } \\
\text { Marine (03.21) and freshwater (03.22) aquaculture }\end{array}$ & 1 - fishing \\
\hline $\begin{array}{l}\text { Extraction of crude petroleum (06.10) and of natural gas (06.20) } \\
\text { Support activities for petroleum and natural gas extraction (09.10) and for other mining } \\
\text { and quarrying (09.90) } \\
\text { Operation of gravel and sand pits; mining of clays and kaolin (08.12) and of salt (08.93) }\end{array}$ & $\begin{array}{l}2 \text { - mining and } \\
\text { energy }\end{array}$ \\
\hline $\begin{array}{l}\text { Processing and preserving of fish, crustaceans and molluscs (10.20) } \\
\text { Wholesale of other food, including fish, crustaceans and molluscs (46.38) }\end{array}$ & 3 - food industry \\
\hline $\begin{array}{l}\text { Building of ships, boats and floating structures, including pleasure and sporting boats } \\
\text { (30.1, 30.11, 30.12) and } \\
\text { Repair and maintenance of ships and boats (30.15), machinery (33.12) and dismantling } \\
\text { of wrecks (38.31) }\end{array}$ & $\begin{array}{l}4 \text { - building of ships } \\
\text { and boats }\end{array}$ \\
\hline Works related to construction of water projects (42.91, 42.99) & $\begin{array}{l}5-\text { construction of } \\
\text { water projects }\end{array}$ \\
\hline
\end{tabular}




\begin{tabular}{|l|l|}
\hline Sea and coastal passenger and freight water transport $(50.10,50.20)$ and inland & 6 - water transport \\
passenger and freight water transport $(50.30,50.40)$ & \\
Service activities incidental to sea transportation $(52.22,52,29)$ & \\
Warehousing and storage and cargo handling in sea ports $(52.10,52.24)$ & \\
\hline $\begin{array}{l}\text { Research and experimental development on biotechnology and natural sciences and } \\
\text { engineering }(72.11,72.19)\end{array}$ & $\begin{array}{l}7 \text { - research \& } \\
\text { development }\end{array}$ \\
\hline $\begin{array}{l}\text { Hotels, holiday and other short-stay accommodation, amping grounds and campsites } \\
(55.10,55.20,55.30)\end{array}$ & 8 - tourism \\
Restaurants and other eating places (56.10) \\
$\begin{array}{l}\text { Rental and leasing of recreational and sports goods and water transport equipment } \\
\text { (77.21, 77.34) }\end{array}$ \\
Tour agents activities (79.11)
\end{tabular}

Source: own elaboration based on [8].

\subsection{A proposal of evaluating local marine economy}

The term 'maritime economy' is used to denote economic activity (not economic value), being measured through the number of business establishments (entities of national economy included in the business register - REGON) [cf. 1]. This approach is determined largely by availability of data at the local level. Statistical data concerning the number of entities were obtained from the REGON database. For a tourism-related group, the number of facilities and accommodation places available in tourist accommodation facilities was used as an index value (this stems from the fact that lots of entities providing accommodation are not registered in the REGON database). The use of REGON database entails certain limitations concerning the accuracy of conclusions. Spatial attribution of information concerns the place of registration rather than the actual place where business activity is carried out. The database covers also firms that ceased to operate, i.e. those that have not deregistered. These and other weaknesses of REGON database are well described in the literature of the subject [e.g. 16, 17]. However, it seems that in spite of the aforementioned drawbacks the database allows for comparing the intensity/volume of maritime economy between communes (gmina, LAU 2), since the similar scale of error maybe assumed with regard to all of the investigated communes, except for large cities where undoubtedly greater number of larger firms is registered, including those that operate outside their area. That is why the REGON database does not always ensure the accuracy of estimations concerning the importance of maritime economy in large urban centres.

To evaluate maritime economy at the local level, particularly to identify regions in which maritime activities play a particularly important role, as well as to conduct comparisons inside the coastal regions, the index method was employed which is regarded to be a traditional research method in socio-economic geography [18]. The basic index that is helpful in differentiating between communes' economic space falling within the framework of maritime sector is the number of economic entities per 10 thousand working age population.

Additionally, in order to enhance the knowledge on the situation existing and processes going on in the coastal regions' economic space, as well as on the basic structures of maritime economy and their evolution, the classification methods were made use of. To carry out classification of communes, multidimensional comparative analysis concerning importance and structure of maritime economy in maritime communes was utilized, with a special focus on development of tourism - classification of facilities performed by means of Ward's method based on the set of features. Two analyses were carried out: for the year 2016 (static analysis) and for the years 2011-2016 (dynamic analysis).

For the purposes of classification of communes, variables are utilized that as far as possible comprehensively characterize maritime economy, while ensuring completeness and comparability of data. The adopted concept of study includes three main areas of 
maritime economy analysis, i.e. (a) based on static approach - importance of sector (entities in maritime economy per 10 thousand working age population, share of entities in maritime economy in relation to the total number of entities), sector's structure (share of entities in the particular sectors of maritime economy in relation to the number of entities in maritime economy), and tourism potential (number of accommodation places in total per 10 thousand population, share of year-round accommodation/hotel accommodation in relation to the total number of accommodation) as the important components of blue economy in Poland; as well as (b) based on dynamic approach (2011-2016 - dynamics of maritime economy sector (dynamics of entities in marine economy, changes in share of entities in marine economy in relation to entities in total), durability of maritime economy structure (change in share of entities in particular sectors of maritime economy in the number of entities in maritime economy), as well as changes in tourism development in communes (dynamics of the number of accommodation places in total, changes in share of year-round accommodation/hotel accommodation in relation to the number of accommodation places in total) representing potential structural changes of marine economy.

Two spatial scopes of study were made use of, to which the separate scopes of marine economy sectors were attributed (both narrow and broad approach to marine economy; cf. Tab. 1 - section 2.2). The former one covers the territory of whole country broken down into communes (LAU 2), and the latter level of analysis was limited to coastal communes. Delimitation of coastal regions constitutes a compromise between different interactions and relations between sea and land as well as objectives of the study itself. In European studies carried out at the regional level, those statistical regions (NUTS 3) which have at least half of their population within $50 \mathrm{~km}$ of the coast (according to Eurostat definition) are recognized as coastal regions. For the purposes of the current study it was assumed that the communes lying directly by the sea, as well as those not lying by the sea, but located within $10 \mathrm{~km}$-wide belt from the sea are regarded as coastal communes, after the "Study of landuse conditions for Polish coastal regions" [19]. According to this approach, in total, coastal regions comprise 68 LAU 2 units (communes) (spatial scope against the background of the whole country - cf. Fig. 1).

\section{Results}

\subsection{Polish local marine economy}

The findings obtained from the countrywide analyses show evident clustering of maritime economy especially in maritime communes (Fig. 1). In this context, it comes as a surprise that there are so many maritime economic entities operating in inland regions of Poland. This is due to taking into account, under the framework of that sector, economic establishments involved in the construction of water-engineering facilities, as well as those that carry out maritime-related research. The research studies go to the benefit of large cities. Nonetheless however, by using this approach, it was possible to establish that in all of the maritime communes the number of economic entities exceeds 10 , while in the areas characterized by outstanding tourist values and in large seaside cities that number exceeds 50 per 10 thousand working age population.

Inclusion of the measurement of importance of maritime economic sector at the local level, covering the whole country, makes it thus possible to prove the thesis that a marked spatial diversification in location of maritime-related sector of economic entities stems from a varying degree of relation, under the maritime economy activity, to the seaside location (sectors benefiting from the location rents, as well as those independent of/dependent in a small degree upon location in the seaside areas, e.g. part of scientific 
research, food processing, etc.). On the other hand, it reveals certain weaknesses in operationalization of the maritime economy concept based on a statistic system of economic activity classification and on necessity to adopt numerous assumptions.

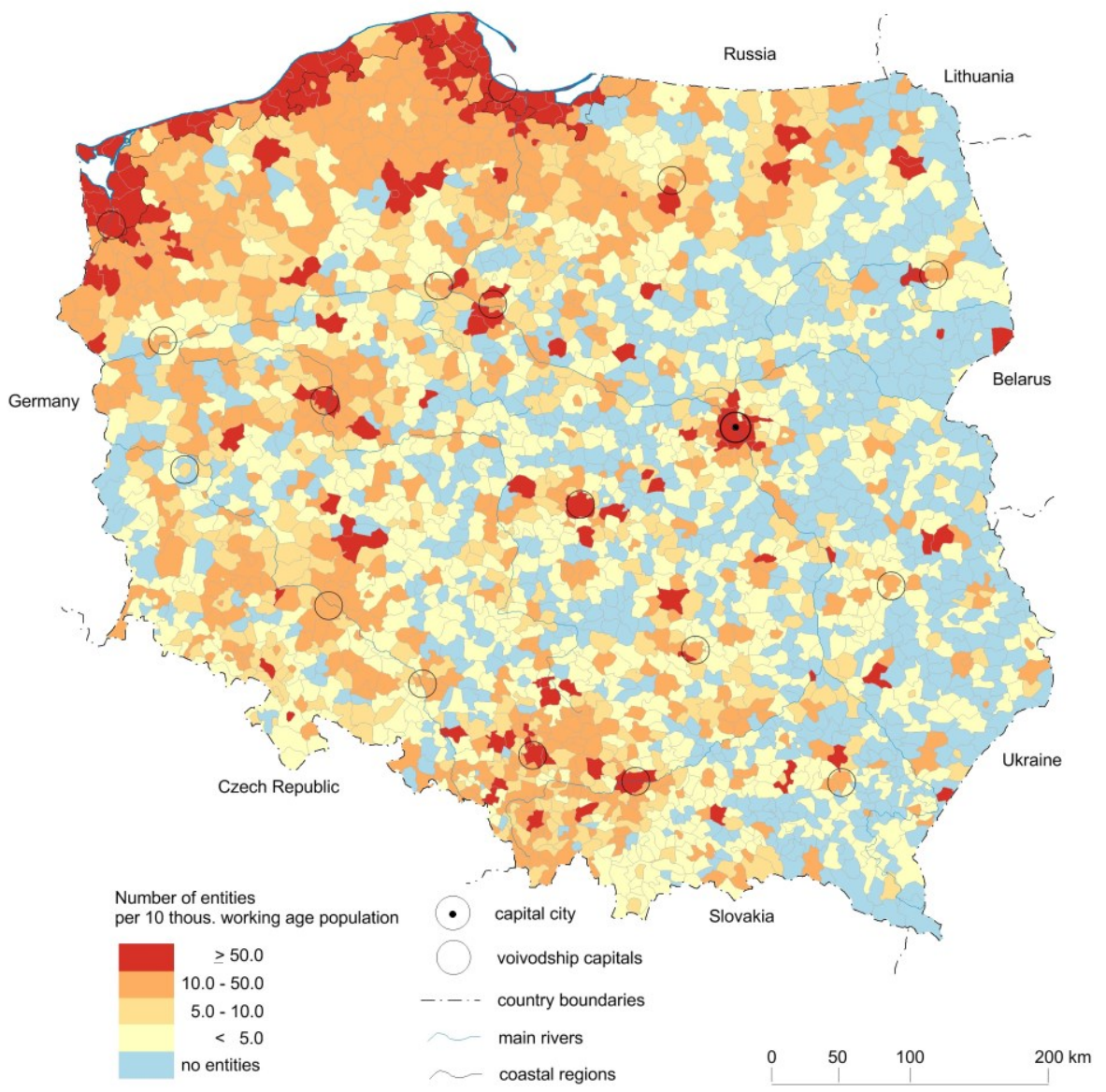

Fig. 1. Number of REGON entities potentially related to marine economy per 10 thousand working age population, as of the end of 2016.

Source: own elaboration based on [8].

\subsection{Coastal Poland local marine economy}

In order to find solutions to part of the problems posed by definitional approach to the maritime economy scope at the local level, perhaps it would be necessary to limit the spatial analysis exclusively to seaside areas. That is why analogical studies on the importance of maritime economy sector locally were carried out with regard to seaside communes. Sector of maritime economy (in a broader object-based approach including inter alia tourism, warehousing, cargo handling) shows considerable spatial differentiation in regard to seaside communes (Fig. 2). As regards quantitative-based approach, the majority of entities is concentrated in large coastal cities (Gdańsk-Gdynia-Sopot and Szczecin) and in communes adjacent to them.

The exception is the tourist sector located along the coast in smaller municipalities and towns, and occurring in rural and urban-rural communes and small coastal towns: fishing, fishing industry and the production of ships and boats appearing in many different 
communes. In total, approximately 22 thous. entities of maritime economy were located in coastal areas of Poland in 2016.

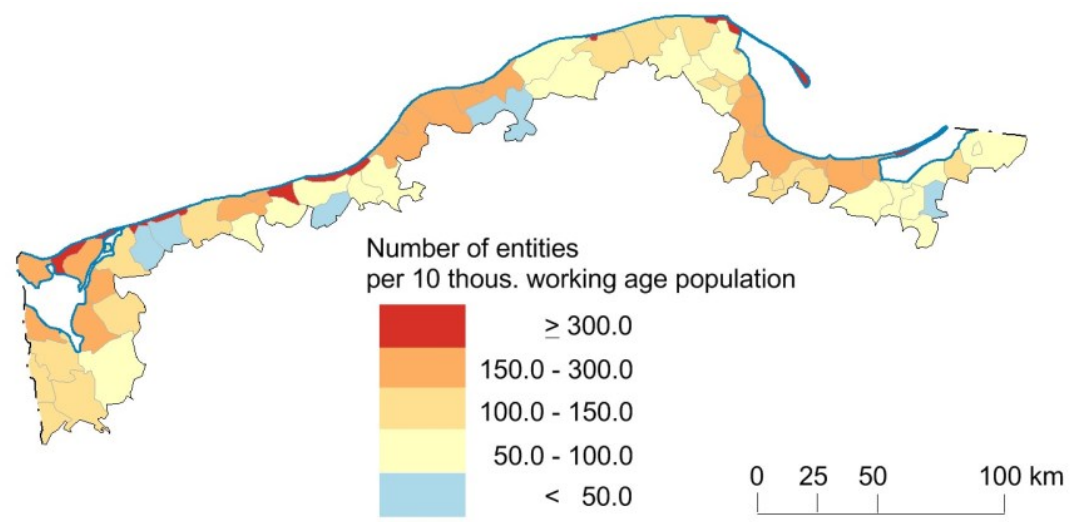

Fig. 2. Number of REGON entities related to marine economy per 10 thousand working age population, as of the end of 2016

Source: own elaboration based on [8].

Spatial analysis of the number of economic entities per 10 thousand working age population indicates that maritime economy is of a relatively great importance to small towns and rural communes (Hel, Jastarnia, Władysławowo, Sztutowo, Krynica Morska, Łeba, Mielno, Ustronie Morskie, Rewal, Dziwnów, Kamień Pomorski). The number of maritime economic entities exceeds 300 per 10 thousand working age population. On the other hand, there occur communes - none of which is lying directly by the sea - with a relatively small number of entities. Against this backdrop, large cities, due to their larger and more diversified economic base, are in the group of areas characterized by an average intensity/volume of maritime economy.

\subsection{Types of maritime communes based on importance and structure of marine economy}

\subsubsection{Static typology}

Based on the use of static method of classification, 5 groups of communes have been identified. Group 1 consists primarily of large multifunctional centres together with their surrounding zones that specialise in "higher-order" sectors of maritime economy: ship and boat building, water engineering constructions, water transport, including even, to a relatively high degree, scientific research. Also the tourism infrastructure, in opposition to units from groups $3-5$, is made up chiefly of hotel accommodation base, which partly results from the fact that it provides also business-oriented services. However, it needs to be stated that the marine sector is just one of many sectors that operate within these centres. Group 2 is made up of communes, similarly as in the case of group 1, with diversified character of marine sector which includes mainly tourism (prevalence of hotel facilities), ship and boat building as well as fishery. The marine economy plays a noticeable role in economy of these communes, but its share is lower than in communes representing 4 and 5 types. In turn, group 3 consists of communes in which, as compared to other groups, the marine economy does not play a particular part in economy; these communes are predominantly small multifunctional centres. Group 4 is made up of communes that have moderate significance for marine economy and average tourist-oriented services. An important role is played especially by these units that are also centres associated with 
fishery and fishing industry, as well as with ship and boat building. Group 5, the least numerous one, consists of units with strict tourism specialization; these are the communes with the largest concentration of marine economic entities - in which the marine sector to greatest extent is linked to tourism (mostly monofunctional in character) - food and beverages establishments, tourist traffic services and primarily holiday centres (often seasonal). In addition to tourism, fishery is a sector of great importance. Groups 2 and 3 are made up of units that distinguish themselves by differentiated location in relation to coastal line - with small exceptions these are the communes which are not immediately situated on the coast of the Baltic Sea. Group 4 and 5 includes communes that are located alongside the Baltic coast. Figure 3 presents location of particular groups.

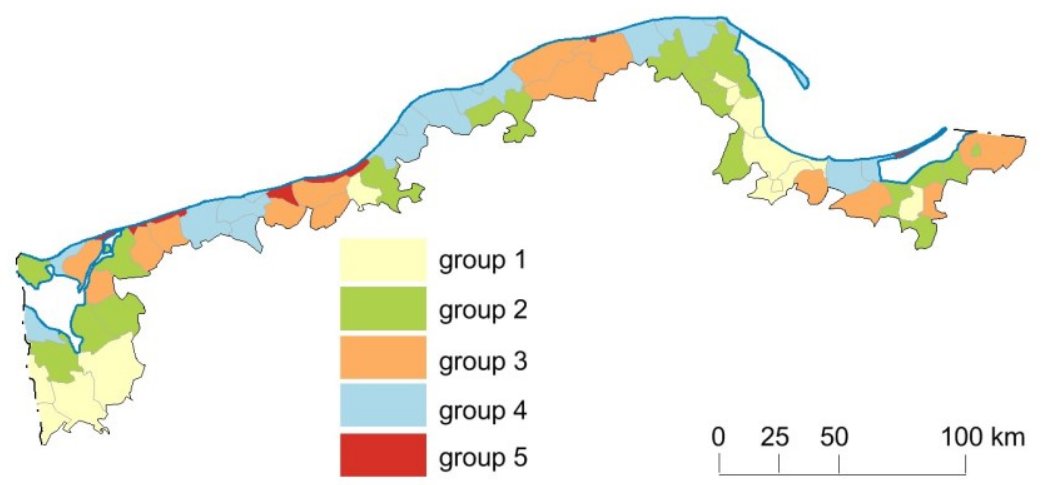

Fig. 3. Typology of maritime communes in regard to maritime economy criteria (static analysis) Source: own elaboration based on [8].

\subsubsection{Dynamic typology}

Thanks to the use of classification method based upon dynamic approach, similarly as in the above-mentioned case, 5 groups of communes have been identified; however, it must be stated that their numerical distribution is even more unequal than the one elaborated on the basis of static approach. The most numerous group (1) constitute communes characterised by an average growth of maritime economy, as well as by stable structure of that industry sector. A characteristic feature of units belonging to group 2 is a relatively high dynamics of marine sector (second position in the ranking after group 5). The changes are additionally influenced by structural transformations, a decrease in significance of fishery as well as of construction of water engineering and tourist facilities, and simultaneously by a growing importance of ships and boats building. An extremely high dynamics of accommodation places is accompanied by an increased seasonality of the tourist accommodation infrastructure that follows from the rapid growth in number of seasonal places. Group 3 is made up of units which, under conditions of stabilised importance of maritime industry sector as well as of its structure, are characterised by the highest increase of entities in absolute numbers. In the area of tourism, it should be noted that there occurs a drop in share of year-round accommodation places (similarly as in group 2). These communes are characterised by high levels of coastal tourism development (high increases in absolute numbers, but with small relative increments). Also, they distinguish themselves by a high percentage of continuing businesses. Group 4 comprises units with a stable maritime industry sector, however, with a tendency towards decreased importance of that industry sector (including tourism sector). Nevertheless a large percentage of companies continues to enjoy a stable situation in the area of undertaken activity. Considering the structure of the industry sector, it is the only group in which a slight 
increase of fishing importance is noted. In turn, group 5 comprises communes where the maritime sector, as measured in terms of economic entities number, is developing at the most dynamic pace. Also, as it is observed, there occur such processes as the qualitative improvement of accommodation places (with a simultaneous decrease of their overall number), the highest growth of year-round accommodation places in hotel facilities, which is partly due to their extremely low initial level, and the largest increase of entities in the tourism sector. At the same time, however, tourism is losing its importance in favour of those activities that are associated with ship and boat building as well as water transport.

Figure 4 presents map showing division of maritime communes based on dynamic approach. Spatial distribution of communes, performed by means of Ward method, reveals some regularities, namely a relatively rapid growth of maritime economy in communes where previously this sector of economy never had much significance, also in the communes that are not located at the immediate location on the Baltic shore. St the same time, it reveals that there is an ongoing stabilization in development of that industry in typical tourist communes and in large multifunctional centres together with their surrounding zones that specialize in "high-order" maritime economy sectors.

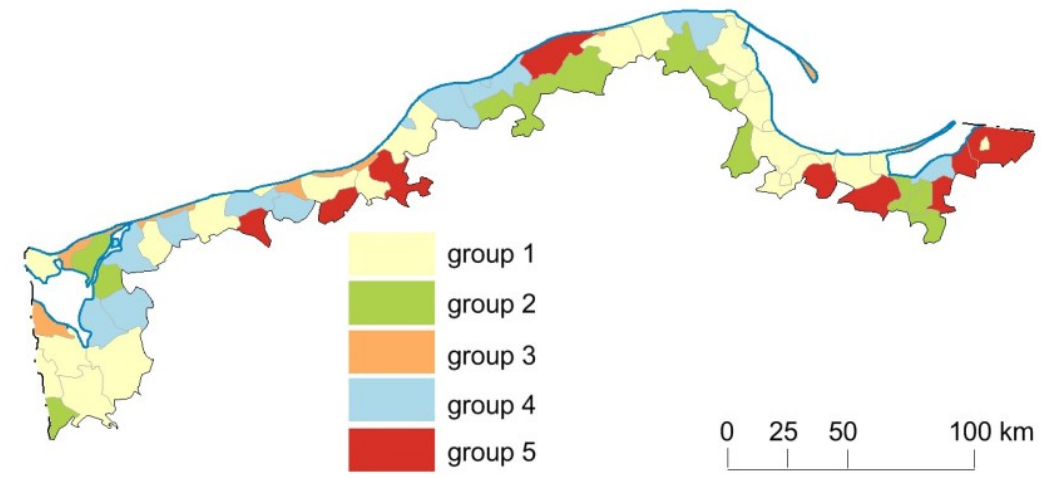

Fig. 4. Typology of maritime communes in relation to marine economy criteria (dynamic analysis) Source: own elaboration based on [8].

\section{Conclusions}

Identification of the importance of maritime economic sector (in a narrow sense) at the local level in Poland, based on the index of the number of economic entities per 10 thousand working age population, tends to denote: (a) a high level of heterogeneity of Poland's economic space, (b) a concentration of strong links with maritime economy in the areas situated especially along the coastal line (traditionally predisposed toward stronger links with that sector), (c) trends towards concentrating business activity in the sectors connected with maritime economy also in the agglomeration areas (marine activity independent of location in the direct vicinity of the Baltic sea), and last (d) that the large part of Poland's space has no links whatsoever with maritime economy (this concern in the main the peripheral areas located in east Poland, as well as the so-called inner peripheries). The similar studies in foreign literature deal more often with attempts to identify disparities in maritime economy at the regional rather than the local level. Hence the utilized set of features is based primarily on indicators concerning GDP (or GVA), labour productivity within the marine sector or the level of employment in marine economy sectors. Nevertheless their results reveal that regional disparities are significant among regions and also that regional sectoral specializations are developing [12, 20, 21], the ocean economy plays a greater role in absolute terms predominantly in urban areas, however, it has greater significance for less developed local economies (including rural areas) [1], and, in certain 
cases, gaps between maritime economies of varied coastal regions are gradually decreasing [21].

Analysis of the maritime sector (in a broader approach as compared to analysis of the area of the whole country), limited spatially to coastal regions, reveals strong spatial differentiations between communes in terms of significance of maritime economy, both among economic entities (in addition to communes characterized by a very high index of economic entities per 10 thousand population - small administrative units that have coastal location, there are communes that have a relatively insignificant links with maritime economy, including also those that are situated along the Baltic coast), and in terms of accommodation offer (in this case spatial distribution is to a larger extent related to the distance from the shore - seaside municipalities are among the most tourist-wise developed localities). The large heterogeneity of maritime areas in terms of development of maritime economic sector is also noticeable with reference to the European Atlantic areas (the highest level of heterogeneity is noted in case of Portugal regions), where at the coastal NUTS 3 level, to measure and compare the importance of the maritime sectors, a synthetic index value was utilized (the EcIMar index) [22].

The index method, applied for evaluation of the level and significance of maritime economy on a local scale, can be further developed on a number of aspects: (a) broadening the list of indices with the ones that concentrate on a sectoral structure of maritime economy or (b) paying attention to dynamics of change in maritime economy. Spatial classifications provide more opportunities for locally-oriented studies of the marine economy sector. The presented typologies have innovative character; in the Polish literature of the subject, one can hardly find any cases of communes' classifications where the maritime economy would serve as a principal classification criteria. This indicates that the economic dimension revolving around the junction between land and sea has been greatly undervalued by Polish researchers. The presented findings can be compared to classifications covering either all Polish communes [23], or communes that have a specific economic profile, e.g. rural communes [e.g. 24], or tourist communes [e.g. 25, 26]. The typology proposed in the current study provides, however, other, greatly important aspects to the knowledge of maritime communes. For example, a group of communes identified by Śleszyński and Komornicki [23] with other non-agricultural functions can be broken down into communes that have evident tourist profile (group five) and those where multifunctional maritime economy is developing (group four). While with regard to communes having other functions, the typology pinpoints e.g. those with greater (group two) and those with lesser (group three) significance for maritime economy. In the foreign literature, there have been sporadic studies that use hierarchical agglomerative clustering for determining the regional regularities within blue economy. For example, Fernandez et al. [27] based on the use of Ward's method grouped regions of Atlantic European Arc, indicating, as a result, mostly nation-driven maritime clusters, which attests to the fact, that such studies ought to be carried out within the particular countries, aiming at analysis of intrastate trends. Summing up, the initial assumptions for the typology employed and choices made concerning the necessity to separately classify dynamic and static phenomena have been confirmed to be correct. Dynamic classification brings completely new knowledge, being in addition an innovative way of looking at the dynamics of changes taking place in maritime communes in the context of marine economy.

Identification of territories, characterized both by a high as well as low importance of maritime economy, may be useful in determining the economic potential of the aforesaid sector at the local level and in pursuing the policy of improving competitiveness. Blue Growth and spatial planning in the seaside regions, including location of strategic investments with specific reference to a place-based approach. At the same time, a much 
greater emphasis should be put on a comprehensive approach to the subject-matter of local maritime economy.

The paper presents the outcomes of the research financed by the Polish National Science Centre under the project "Economy of maritime space" (2015/17/B/HS4/00918).

\section{References}

1. C. S. Colgan, The ocean economy of the United States: Measurement, distribution, \& trends, Ocean \& Coastal Management, 71, 334-343 (2013) DOI: http://dx.doi.org/10.1016/j.ocecoaman.2012.08.018

2. L. D. Rodwell, S. Fletcher, G. A. Glegg, M. Campbell, S. E. Rees, M. Ashley, E. A. Linley, M. Frost, B. Earll, R. B. Wynne, L. Mee, P. Almada-Villela, D. Lear, P. Stanger, A. Colenutt, F. Davenport, N. J. Barker Bradshawk, R. Covey, Marine and coastal policy in the UK: Challenges and opportunities in a new era, Marine Policy, 45, 251-258 (2014) DOI: http://dx.doi.org/10.1016/j.marpol.2013.09.014

3. J. Zaucha, Sea basin maritime spatial planning: A case study of the Baltic Sea region and Poland, Marine Policy, 50, 34-45 (2014) DOI: http://dx.doi.org/10.1016/j.marpol.2014.05.003

4. M. R. Keen, A.-M. Schwarz, L. Wini-Simeon, Towards defining the Blue Economy: Practical lessons from pacific ocean governance, Marine Policy, 88, 333-341 (2018) DOI: http://dx.doi.org/10.1016/j.marpol.2017.03.002

5. Uchwała $n r$ 33/2015 Rady Ministrów z dnia 17 marca 2015 r. w sprawie Polityki morskiej Rzeczypospolitej Polskiej do roku 2020 (z perspektywa do 2030 roku) (2015)

6. Green paper towards a future maritime policy for the Union. European vision for the oceans and seas (European Commission, Brussels 2006)

7. Communication from the Commission to the European Parliament, the Council, the European Economic and Social Committee and the Committee of the Regions concerning the European Union Strategy for the Baltic Sea Region (Brussels, 2009)

8. J. Zaucha, Gospodarowanie przestrzenia morska (Instytut Rozwoju, Sopot, 2018, to be published)

9. M. G. Burgess, M. Clemence, G. R. McDermott, C. Costello, S. D. Gaines, Five rules for pragmatic blue growth, Marine Policy, 87, 331-339 (2018) DOI: http://dx.doi.org/10.1016/j.marpol.2016.12.005

10. K. S. Park, J. T. Kildow, Rebuilding the Classification System of the Ocean Economy, Journal of Ocean and Coastal Economics, 2014, 1, 4 (2014) DOI: https://doi.org/10.15351/2373-8456.1001

11. J. C. Surís-Regueiro, M. D. Garza-Gil, M. M. Varela-Lafuente, Marine economy: A proposal for its definition in the European Union, Marine Policy, 42, 111-124 (2013) DOI: http://dx.doi.org/10.1016/j.marpol.2013.02.010

12. C. S. Colgan, Measurement of the ocean and coastal economy: theory and methods (National Ocean Economics Project, USA, 2004)

13. Rocznik Statystyczny Gospodarki Morskiej (Główny Urząd Statystyczny, Urząd Statystyczny w Szczecinie, Warszawa, 2016)

14. T. Brodzicki, J. Zaucha, Analiza "niebieskiego wzrostu”, polityki morskiej oraz strategii UE dotyczacej Regionu Morza Bałtyckiego. Analiza dla Polski (Dokumenty robocze Instytutu Rozwoju, 4, 2013)

15. D. P. Shaw, S. Kidd, L. McGowan, S. A. Jay, ESaTDOR: European Seas and Territorial Development, Opportunities and Risks, Final Report (Luxembourg, ESPON, the European Observation Network for Territorial Development and Cohesion, 2013) 
16. P. Śleszyński, Studium szacunku liczby i rozmieszczenia pracujących w Krakowie (Biuletyn KPZK PAN, 243, 2010)

17. D. Celińska-Janowicz, Rejestry podmiotów jako źródła danych w analizach lokalizacji działalności gospodarczej w mikroskali, Wiadomości Statystyczne, 1, 27-43 (2016)

18. Z. Chojnicki, Dylematy kwantyfikacji geografii, [w:] Z. Chojnicki (red.) Metody ilościowe i modele w geografii (PWN, Warszawa, 9-15, 1977)

19. J. Zaucha, M. Matczak, J. Pardus, J. Faściszewski, J. Rekowska, S. Dendewicz, L. Jastrzębski, D. Nowoświecka, M. Nowotarska, J. Smutek, T. Jaksina, R. Woziński, M. Izdebski, P. Kaszczyszyn, H. Boniecka, A. Gajda, M. Adamowicz, T. Łączkowski, E. Kuzebski, P. Margoński, T. Nermer, W. Pelczarski, I. Psuty, M. Rakowski, L. Szymanek, U. Kowalczyk, M. Kalinowski, B. Szwankowska, W. Kuszewski, M. Szymańska, B. Hac, J. Gajewski, M. Kałas, J. Kapiński, R. Wróblewski, P. Brzeska, L. Kruk-Dowgiałło, M. Gorczyca, I. Kordala, T. Kuczyński, M. Michałek, M. Olenycz, A. Osowiecki, P. Pieckiel, J. Przedrzymirska, I. Rakowska, T. Komornicki, Studium Uwarunkowań Zagospodarowania Przestrzennego Polskich Obszarów Morskich (Gdańsk, Instytut Morski w Gdańsku, 2015)

20. K. Morrissey, C. O'Donoghue, The Irish marine economy and regional development, Marine Policy, 36, 358-364 (2012) DOI:10.1016/j.marpol.2011.06.011

21. L. Baiqiong, X. Min, W. Jing, X. Sumei, Regional disparities in China's marine economy, Marine Policy, 82, 1-7 $\quad$ (2017) DOI: http://dx.doi.org/10.1016/j.marpol.2017.04.015

22. J. Fernández-Macho, P. González, J. Virto, An index to assess maritime importance in the European Atlantic economy, Marine Policy, 64, 72-81 (2016) DOI: http://dx.doi.org/10.1016/j.marpol.2015.11.011

23. P. Śleszyński, T. Komornicki, Klasyfikacja funkcjonalna gmin Polski na potrzeby monitoringu planowania przestrzennego, Przegląd Geograficzny, 88, 4, 469-488 (2016)

24. J. Bański, M. Mazur, Classification of rural areas in Poland as an instrument of territorial policy, Land Use Policy, 54, 1-17 (2016) DOI: 10.1016/j.landusepol.2016.02.005

25. T. Lijewski, B. Mikułowski, J. Wyrzykowski, Geografia turystyki Polski (PWE, Warszawa, 2008)

26. S. Sobotka, Próba wyznaczenia obszarów o najwyższym stopniu wykorzystania turystycznego jako przesłanki do regionalizacji turystycznej Polski, Turyzm, 24/2, 3543 (2014)

27. J. Fernández-Macho, A. Murillas, A. Ansuategi, M. Escapa, C. Gallastegui, P. González, R. Prellezo, J. Virto, Measuring the maritime economy: Spain in the European Atlantic Arc, Marine Policy, 60, 49-61 (2015) DOI:http://dx.doi.org/10.1016/j.marpol.2015.05.010 